\title{
Seni Lukis sebagai Refleksi Ketidakberdayaan dan Keterpinggiran Cokek
}

\author{
SARNADI ADAM \\ Program Doktor Institut Seni Indonesia Yogyakarta \\ E-mail: sarnadi_adam@yahoo.co.id
}

Penelitian ini didorong oleh kerinduan peneliti pada Tari Cokek sebagai bagian dari lingkungan budaya pada masa silam untuk menjadi inspirasi seni lukis. Setelah dilakukan studi literatur, observasi, wawancara dan pendokumentasian, ditemukan fakta, bahwa masyarakat pendukung Cokek telah semakin menurun, sehingga kesenian ini tidak berdaya untuk mempertahankan eksistensinya, ditandai dengan terpinggirnya Cokek dari pusat Jakarta ke Tangerang. Para pelaku Cokek mengalami dilema atau berada dalam pilihan yang sulit: untuk bertahan, penanggap telah semakin langka, sedangkan untuk beralih profesi mereka tidak memiliki keahlian lain karena kecintaannya pada Cokek. Dilema tersebut, khususnya pada problem ketidakberdayaan dan keterpinggiran Cokek, menjadi sumber inspirasi utama untuk menciptakan 7 (tujuh) lukisan pasca penelitian. Adapun metode penciptaannya meliputi: eksplorasi ide, bentuk, dan teknik. Hasilnya, sebagai temuan penciptaan, adalah seni lukis dekoratif nostalgis, ialah seni lukis bercorak dekoratif yang mengaktualisasikan rasa rindu dan rasa iba pada Cokek sebagai bagian dari budaya Betawi masa silam yang kini semakin menghilang.

Kata kunci : betawi art tradition, cokek, painting, decorative nostalgic

\section{Painting as Reflection of Powerlessness Marginality of Cokek Dance}

\begin{abstract}
This research is motivated by researchers of Cokek Dance longing to become inspiration for painting of as part of the cultural environment in the past. After the study of literature, observation, interviews and documentation, it was found that Cokek's supporting societies had declined, so that this art tradition was powerless to maintain its existence, marked by the marginalization of Cokek from central Jakarta to Tangerang. Cokek actors are in a dilemma or are in a difficult choice: to survive, the responders have become scarce, while to switch professions they have no other skills because of their love of Cokek. The dilemma, particularly on the powerlessness and marginalization of Cokek, became the main source of inspiration for creating 7 (seven) post-research paintings. The method of creation includes: the exploration of ideas, forms, and techniques. The result, as the invention of creation, is a nostalgic decorative art; a decorative patterned painting that actualizes the longing and pity of Cokek as part of the now disappearing Betawi culture.
\end{abstract}

Keywords : Betawi art tradition, cokek, painting, decorative nostalgic

Peer Review : 2 - 19 Januari 2018, Acepted to Publish 22 Januari 2018

\section{PENDAHULUAN}

Cokek adalah seni tradisi masyarakat etnis Betawi berupa tarian penyambutan tamu oleh beberapa wanita dalam acara perkawinan etnis Cina dengan diiringi nyanyian khas dan musik gamang kromong. Secara visual tarian ini memadukan pengaruh budaya Betawi dan Cina, ditandai dengan penggunaan warna hijau, merah, kuning dan biru. Sebagai orang yang dilahirkan dan dibesarkan di Jakarta, kesenian Beta- wi menjadi bagian dari kehidupan penulis. Termasuk di antara kesenian tersebut adalah Cokek, yang akrab dengan penulis sejak masa kanak-kanak sampai remaja di daerah penulis tinggal, ialah di Kebayoran Lama, Jakarta Selatan. Perasaan gembira, semangat dan larut, masuk dalam suasana yang menyenangkan ketika menonton Cokek yang kerap mengiringi prosesi upacara perkawinan adat Betawi.

Ketika penulis menginjak usia dewasa, Cokek sudah 
tidak ada lagi di Kebayoran Lama, Jakarta Selatan. Cokek telah digantikan oleh dangdut-elekton yang menampilkan biduan-biduan yang berpenampilan seronok. Gerakan-gerakan penari yang gemulai digantikan oleh dangdut dengan model gerakan yang dikenal sebagai goyang ngebor, gergaji dan patah-patah. Tampaknya Cokek mulai ditinggalkan orang sehingga para penari Cokek tidak berdaya dan terpinggirkan. Tidak berdaya yang dimaksud adalah lemahnya kekuatan untuk melawan terpaan budaya populer, ditandai dengan komunitas pendukung yang kian menurun. Adapun pengertian terpinggirkan adalah terasing secara budaya dan geografis.

Cokek kini berada dalam dilema atau menghadapi pilihan yang sulit. Jika memilih bertahan hidup, masyarakat pendukungnya telah semakin berkurang; jika memilih berhenti menari, mereka tidak mempunyai keahlian lain sebagai sumber nafkah. Para penari Cokek bekerja seadanya dan sebisanya, yang penting dapat menyambung hidup. Ada yang menjadi pembantu rumah tangga, tukang cuci, pengojek, tukang kredit, petani, bahkan istri simpanan. Kehidupan yang benar-benar memprihatinkan. Sedangkan di sisi lain mereka masih memiliki tanggung jawab pada keluarga, seperti menyusui dan memasak.

Kenyataan tentang kondisi Cokek di atas menjadi sumber inspirasi untuk divisualisasikan dalam karya seni. Pengalaman estetis pencipta telah berproses dan mengendap dalam waktu yang panjang. Endapan-endapan inilah yang kemudian menjadi sumber inspirasi dalam melukiskan Cokek. Ide dan gagasan kreatif didapat dengan banyak melihat kenyataan, merasakan, mencatat, yang mendorong seniman untuk beraktivitas seni (Santo dkk., 2012:14). Sejak kecil penulis telah melihat, merasakan, dan mencatat dalam pikiran, berbagai hal mengenai seni pertunjukkan Cokek, sehingga penulis memiliki kekayaan ide dan gagasan estetik dalam menciptakan lukisan dengan objek Cokek.

Pengalaman estetik bersifat subjektif, juga objektif, artinya seberapa jauh pengalaman estetik berhasil menarik perhatian subjek, tergantung dari kualitas objektif benda yang diamati (Lipps dalam Ratna, 2007:215). Sedangkan kemunculan pengalaman estetik didorong oleh kepekaan estetik pencipta pada hal-hal yang berkaitan dengan kekayaan budaya yang unik.

Sudah menjadi tugas seniman untuk menciptakan berbagai bentuk karya seni sesuai dengan bidangnya. Sebagai pertanggungjawaban visual, mencipta adalah menyatakan identitas dan eksistensi individu seniman. Soedarso SP (2006:80) menyatakan, bahwa ide atau gagasan emosional seorang seniman harus divisualisasikan dengan baik secara intelektual. Dengan intelektualnya seorang seniman memilih medium untuk berekspresi. Melahirkan ide atau gagasan menjadi sesuatu yang kasat mata adalah aktivitas intelektual, yang bersama emosi melahirkan karya seni.

Dalam penciptaan karya seni tidak saja pertanggungjawaban visual semata, tetapi memiliki kedalaman makna yang terkandung di dalamnya. Dalam hal ini Franz Boas menunjuk adanya dua dampak artistik sebuah karya, yaitu: (1) Kesempurnaan bentuk yang diperlihatkan melalui perlakuan teknik sehingga mencapai standar keunggulan tertentu, sehingga kesempurnaan bentuk berkaitan dengan keunggulan teknik; (2) Gagasan-gagasan yang diasosiasikan dengan bentuk dengan prinsip simbolisme, yaitu ketika sensasi dirangsang bukan oleh bentuk saja, tetapi juga melalui asosiasi antara bentuk dan gagasan yang dimiliki seseorang. Jadi, bentuk menyampaikan makna tertentu (Boas dalam Yustiono, 2004:10).

Kehidupan Cokek dalam dilema ini sangat menggelisahkan penulis. Melalui observasi, penelitian dan pendalaman tentang kehidupan mereka, penulis terobsesi ingin megekspresikannya ke dalam karya seni. Sebagai perupa, penulis tergerak dan mulai merenungkannya, dan renungan ini memunculkan gagasan penciptaan yang dapat dirumuskan sebagai berikut:

Bagaimana mengekplorasi kehidupan Cokek yang mulai terpinggirkan sebagai gagasan kreatif?

Bagaimana mengekspresikan kehidupan Cokek tersebut ke dalam gagasan visual?

Bagaimana mentransformasikan bentuk-bentuk visual kehidupan Cokek menjadi ungkapan-ungkapan artistik ke dalam seni lukis?

\section{METODE PENCIPTAAN}

Dalam penciptaan karya ini langkah yang ditempuh adalah melakukan penelusuran dan pengolahan data. Penelusuran data dilakukan melalui studi literatur, studi faktual, dan studi piktorial. Studi literatur dilakukan untuk menguatkan pijakan teoretis dalam berkarya. Studi faktual dilakukan dengan mengamati realitas faktual kaitannya dengan topik, yakni tari Cokek. Studi piktorial dilakukan untuk mengeksplorasi pelbagai kemungkinan bentuk yang dapat dibuat melalui pengamatan terhadap seni lukis dengan objek seni tari karya para pelukis terkemuka Indonesia. Hal ini guna memetakan bentuk karya sehingga berbeda dengan yang sudah ada. Data yang telah terolah kemudian menjadi pijakan proses pembuatan. 

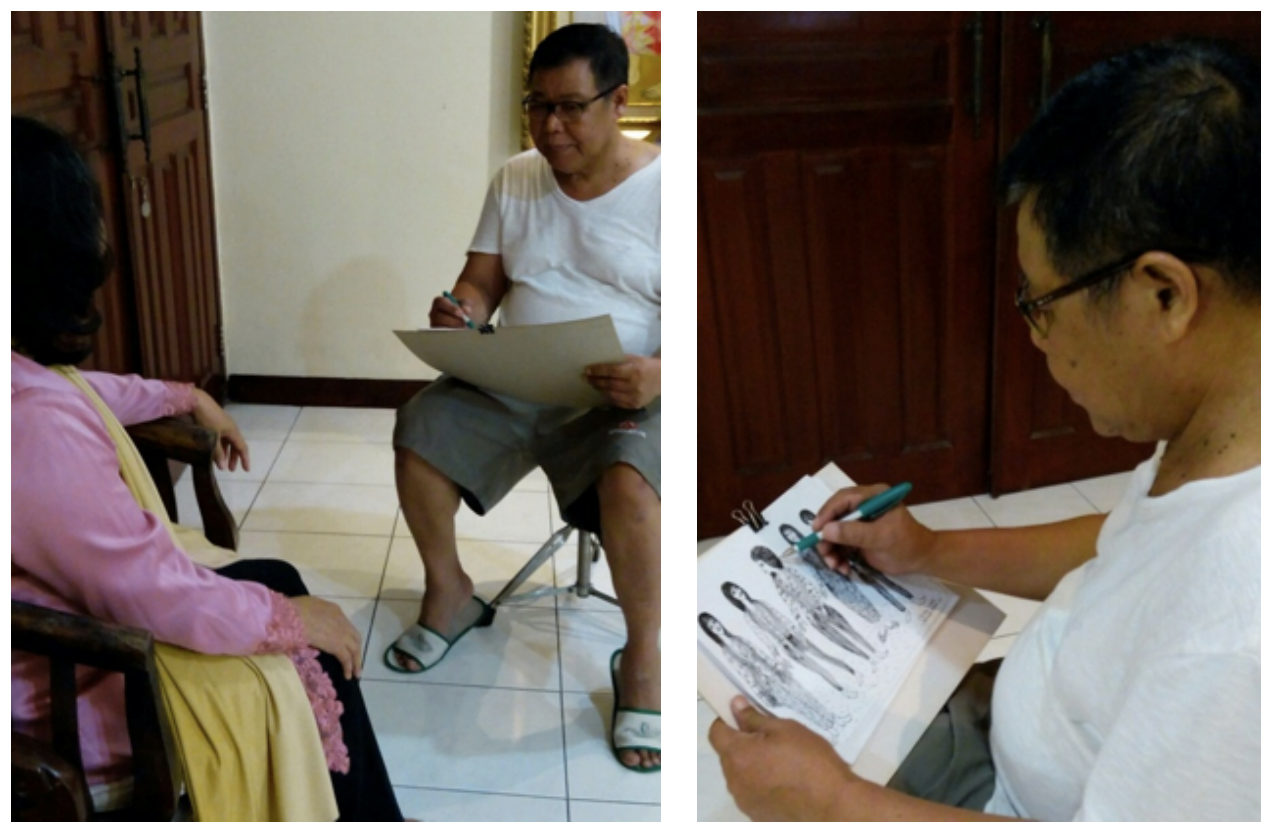

Gambar 1. Proses Sketsa dengan Model Penari Cokek

(Sumber: pribadi, 2016)

Agar penciptaan karya seni ini mencapai tujuan yang diinginkan, sebagai landasannya mengacu pada model yang diusulkan oleh Konsorsium Seni yaitu 5 (lima) tahapan penciptaan yaitu: (1) persiapan, (2) elaborasi, (3) sintesis, (4) realisasi konsep dan (5) penyelesaian atau evaluasi (Bandem, 2001: 10). Lima tahap penciptaan ini saya anggap logis dan bisa mewadahi tahap-tahap yang sifatnya personal. Selain itu perlu juga ditambahkan lima tahap kreativitas dari David Campbell (1986: 18-24) yaitu: 1) Tahap Persiapan, 2) Konsentrasi, 3) Inkubasi, 4) Iluminasi, dan 5) Verifikasi/produksi. Kelima tahapan tersebut dapat dirujuk dalam proses penemuan ide penciptaan dan ide bentuk. Dalam mengemukakan metode pelaksanaan ini, tidak terlalu jauh dengan apa yang selama ini penulis jalani dalam berkarya.

\section{PROSES PERWUJUDAN}

Pembentukan karya sangat ditentukan oleh keputusan senimannya. Seniman memiliki kemampuan cipta, rasa dan karsa untuk melakukan sesuatu sebagai ungkapan atau pernyataan diri di dalam karya. Setiap wujud karya tidak terjadi begitu saja, melainkan lahir dari keinginan menyampaikan sesuatu. Bagaimana menyampaikan sesuatu inilah yang dimaksud sebagai konsep wujud yang merupakan konsep dari struktur permukaan dan juga merupakan tata bentuk di dalam perwujudan karya. Perwujudan karya ditopang oleh media dan teknik yang dipakai, dalam hal ini penulis memakai cat akrilik dengan teknik basah pada bidang kanvas.
ANALISIS

Seniman melalui karya seni yang diciptakan dapat mengungkapkan pengalaman estetiknya terkait dengan lingkungan alam, sosial dan budayanya. Sebuah Karya seni hadir dan berada di tengah-tengah kehidupan manusia merupakan hasil refleksi atas pengalaman hidup manusia. Kerinduan peneliti pada Cokek mendorong peneliti untuk mengamati fenomena ketidakberdayaan dan keterpinggiran Cokek, dan mengekspresikannya secara simbolik ke dalam seni lukis.

Susanne K. Langer (1895) menulis, bahwa simbol merupakan wahana bagi konsepsi manusia tentang objek. Simbol lebih merupakan suatu representasi mental sang subjek, yang sifatnya tidak selalu merangsang subjek untuk bertindak. Hubungan simbol dan objeknya lebih dalam (subtil) dan lebih bermakna. Menurut Ali (2011:203-204), simbol yang otentik dapat juga berasal dari suatu objek, suara, atau tindakan yang tidak memiliki makna praktis, namun cenderung menimbulkan respon emosional.

Adapun dalam melukiskan fenomena Cokek dilakukan dengan memotret objek-objek menggunakan kamera digital, kemudian diekplorasi dengan pengolahan bentuk yang lebih mengedepankan nilai simbolik, ketimbang kenyataan secara fotorelis. Penggabungan antara daya imajinasi fenomena sosial dan hasil jepretan kamera tersebut, adalah sebagai bentuk komunikasi untuk memahami fenomena tersebut dalam menciptakan karya-karya yang unik dan artistik. Dalam jalinan nilai artistik itulah tersirat nilai este- 


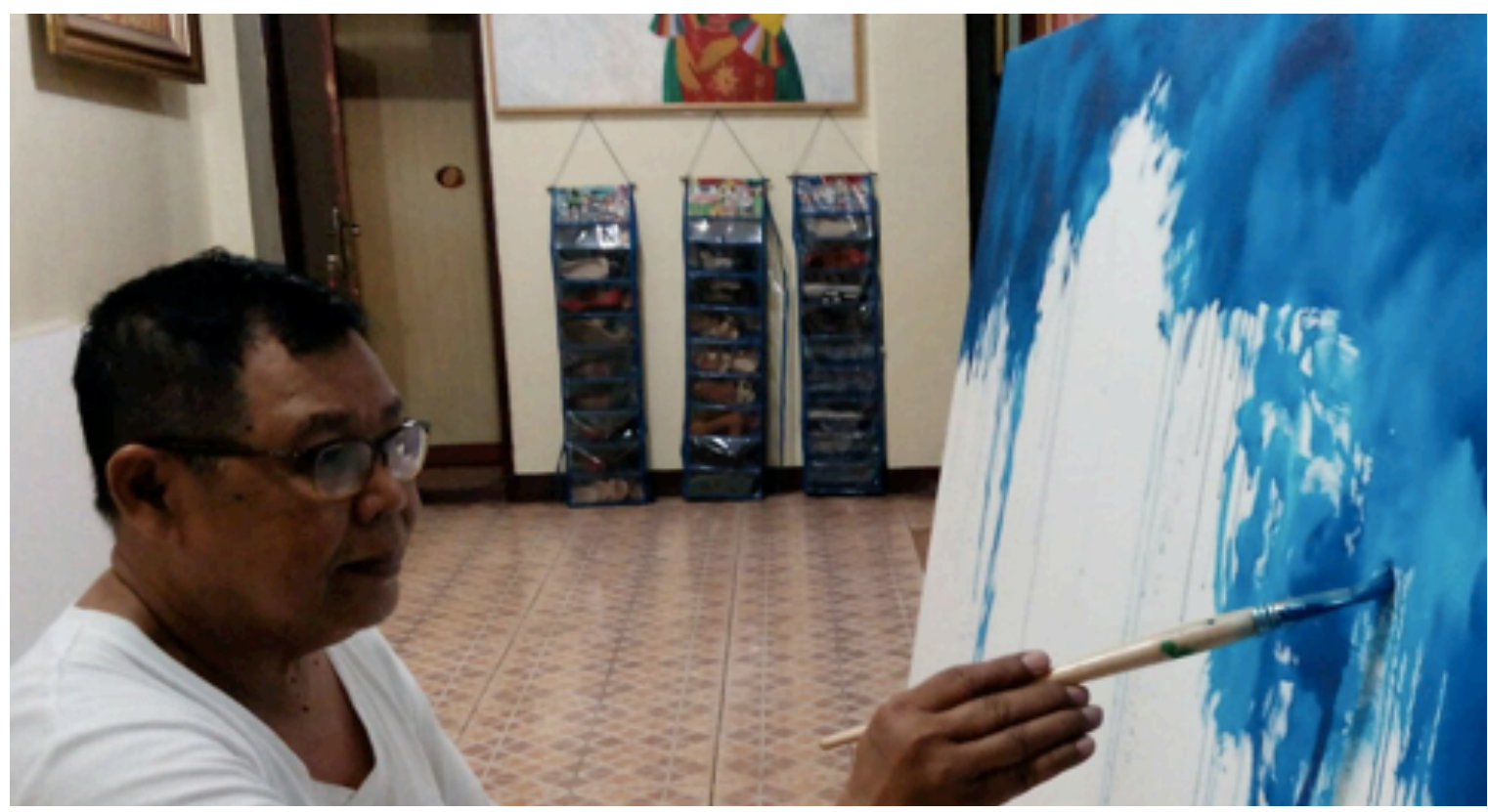

Gambar 2. Proses melukis dengan cat Akrilik pada kanvas

(Sumber: dokumentasi pribadi)

tika yang bersifat simbolik seperti diutarakan oleh Langer. Berikut ini adalah deskripsi singkat dari tujuh karya yang dihasilkan.

Karya pertama, lukisan berjudul Dialog Empat Penari Cokek (gambar 3), menggambarkan empat penari Cokek sedang duduk di depan rumah tradisional Betawi. Semuanya memakai kostum kebaya, kain batik, dan selendang. Latar belakang lukisan ini didominasi warna merah dan eksentuasi bentuk jendela dengan warna kuning kemerahan, dan ornamen stilisasi bentuk matahari. Kostum penari didominasi warna merah, kuning dan hijau, rambut mereka terurai dengan warna hitam dan kulit warna putih kemerahan. Lukisan ini menyimbolkan kerinduan penulis terhadap pesona busana penari cokek. Di samping itu, menyimbolkan empati penulis pada nasib para penari Cokek yang menganggur karena sepinya order pertunjukan. Jeruji pada jendela adalah simbol keterbelengguan jiwa pada budaya yang dicintainya sehingga enggan untuk ditinggalkan.

Karya ke-2, lukisan berjudul Tiga Penari Cokek Menatap Masa Depan (gambar 4), merupakan potret keadaan tiga penari cokek yang merasa senasib dan sepenanggungan sekalipun menghadapi ketidakberdayaan secara ekonomi dan keterpinggiran secara gegrafis. Sebagai penari cokek tradisional, lahannya untuk tampil memperlihatkan kemahirannya sebagai penari cokek semakin terbatas. Kesempatan pentas hanya sebatas undangan dalam acara perkawinan Cina Benteng di rumah kawin Tangerang, yang dalam setahun hanya beberapa kali saja. Saat tidak ada pentas, para penari cokek bekerja serabutan (sebisanya), untuk menyambung kehidupannya. Posisi ketiga penari cokek ditempatkan berdiri di depan rumah tradisional Betawi. Warna pada kostum penari cokek (kebaya, kain batik dan selendang) didominasi warna putih, kuning dan merah dengan latar belakang bentuk pintu rumah Betawi dan bentuk-bentuk ornamen dengan didominasi warna hijau, coklat dan kuning. Ornamen dengan bentuk dasar tumpal, mengesankan sifat kaku (rigid), terikat, dan memusat. Didukung pula dengan pilihan keseimbangan yang cenderung simetris dan pintu yang digambarkan tertutup. Ini semua merupakan simbol-simbol obsesi dan kerinduan penulis pada Cokek dalam kondisi yang asli (orisinal), khas, dan konservatif, sebagaimana layaknya orang yang dirundung kerinduan pada sesuatu yang telah hilang.

Karya ketiga, Lukisan berjudul Delapan Penari Cokek Sehabis Pentas di Rumah Kawin, menggambarkan delapan penari cokek sedang berjalan seperti berbaris. Mereka sedang meninggalkan rumah kawin setelah beberapa saat sebelumnya berpentas. Pentas Cokek itu berlangsung selama berjam-jam, sehingga sangat menguras tenaga. Keletihan tampak dari wajah-wajah mereka yang tanpa senyum. Lukisan didominasi oleh warna merah dan jingga. Pakaian para Cokek digambarkan sangat bervariasi dalam komposisi warna yang cenderung kontras. Demikian juga dengan pakain orang-orang di latar belakang. Penari Cokek digambarkan berada dalam kelompok tersendiri, kerumunan orang di latar belakang. Gambaran demikian merupakan simbol empati penulis 


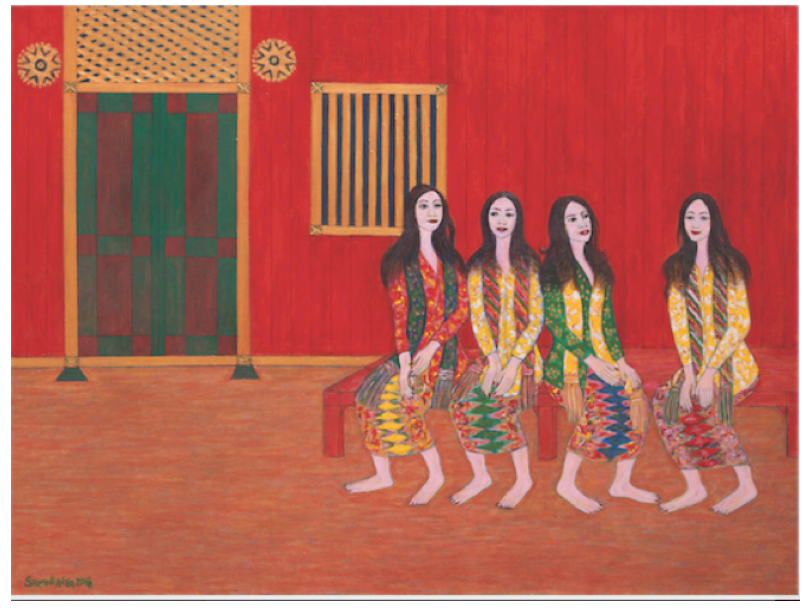

Gambar 3. Dialog Empat Penari Cokek, 2016. Ukuran/ Media: 110 X $80 \mathrm{~cm} /$ Cat akrilik pada kanvas Sumber Foto : Pribadi

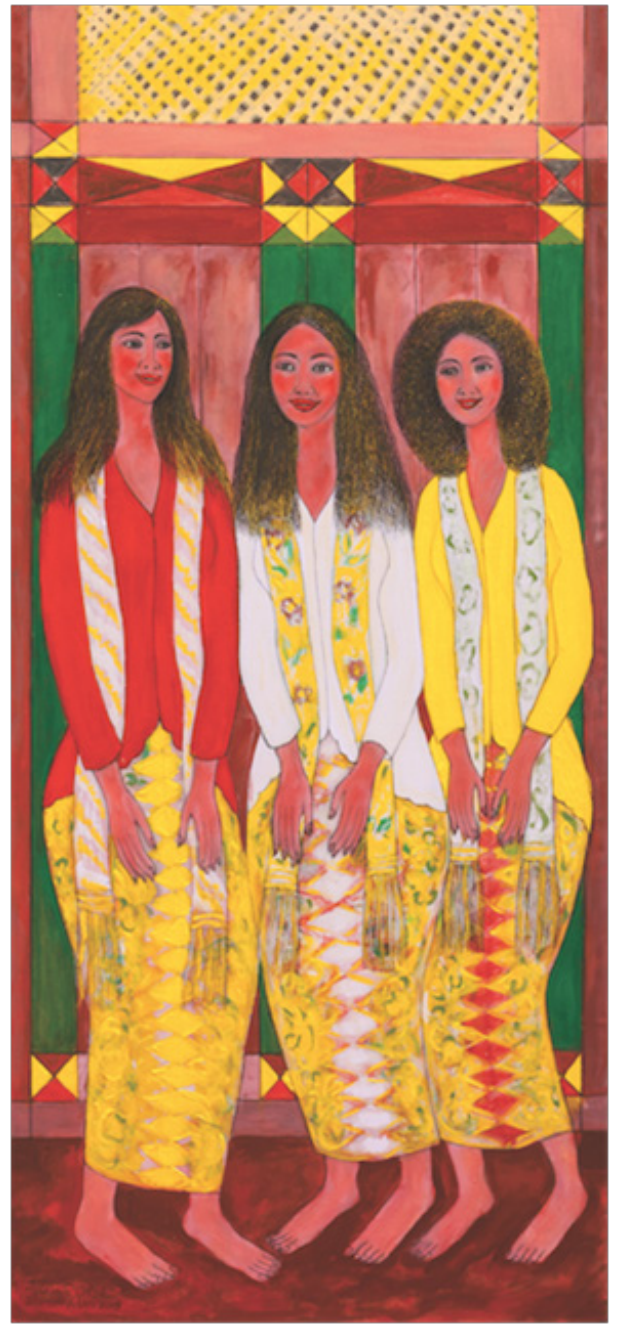

Gambar 4. Tiga Penari Cokek Menatap Masa Depan, 2016. Ukuran dan Media: 110 X $50 \mathrm{~cm} /$ Cat akrilik pada kanvas Sumber Foto: Penulis akan nasib penari Cokek yang terasing dalam keramaian; mereka seperti dinafikan atau dikecualikan dari masyarakatnya. Secara keseluruhan, Delapan Penari Cokek Sehabis Pentas di Rumah Kawin adalah simbol para penari cokek yang kembali ke realitas kehidupan mereka yang tidak berdaya dan terpinggirkan.

Karya keempat, lukisan berjudul Barisan Penari Cokek Menuju Rumah Kawin, adalah gambaran empat puluh satu penari Cokek menuju rumah kawin untuk pentas. Para penari Cokek ada yang berjalan kaki dan ada juga yang naik delman. Mereka tertib berjalan seperti berbaris dan tidak ada yang saling mendahului. Empat puluh satu penari cokek ini menuju rumah kawin (tiga rumah kawin) karena pentas mereka waktunya bersamaan di Teluk Naga dan Kedaung, Tangerang, merupakan tempat rumah kawin yang paling disukai oleh masyarakat Cina Benteng. Sekarang ini dikota Tanggerang dikenal sebagai tempat tampilnya para penari Cokek. Rumah kawin adalah tempat untuk perayaan atau pesta perkawinan Cina Benteng, di Tangerang. Setiap ada pesta perkawinan Cina Benteng, selalu ada pertunjukkan tari Cokek dengan diringi nyanyian dan musik gambang kromong. Disinilah para Cokek pempertunjukkan kemahirannya menemani para tamu untuk ngibing bersama. Lukisan barisan penari cokek menuju rumah kawin dengan pewarnaan didominasi merah, hijau dan biru. Kostum penari cokek beragam warna, ada merah, hijau, kuning dan ungu. Pada bagian depan lukisan figur penari cokek disusun berbaris menuju satu arah dengan tujuan yang sama yaitu rumah kawin. Dikejauhan nampak figur-figur penari cokek dengan pohon-pohon yang rindang. Lukisan ini menyimbolkan empati penulis pada Cokek yang terpinggirkan secara geografis. Menuju tempat pentas bagi para Cokek adalah beranjak dari realitas hidup mereka yang sepi dan terasing, menuju ke keramaian dan penyatuan diri dengan masyarakat pendukungnya. Realitas hidup yang sepi dan terasing tersebut digambarkan melalui latar belakang yang terdiri dari sepenuhnya deretan pohon dan lahan yang kosong, didukung dengan warna langit biru yang berkesan dingin.

Karya ke-5, lukisan berjudul Barisan Penari Cokek Menari, menggambarkan 28 penari Cokek sedang berdiri berjajar dengan pakaian lengkap. Kondisi berjajar demikian menunjukkan mereka siap pentas dalam acara perkawinan Cina Benteng di rumah kawin di Tangerang. Saat seperti itu, banyak para tamu undangan yang berdatangan, terutama pria untuk ngibing bersama Cokek. Selendang yang dikenakan oleh penari Cokek lazim digunakan untuk menggaet tamu laki-laki dengan cara mengalungkannya ke leher pria. Pada tarian Cokek, yang dominan adalah kedipan 


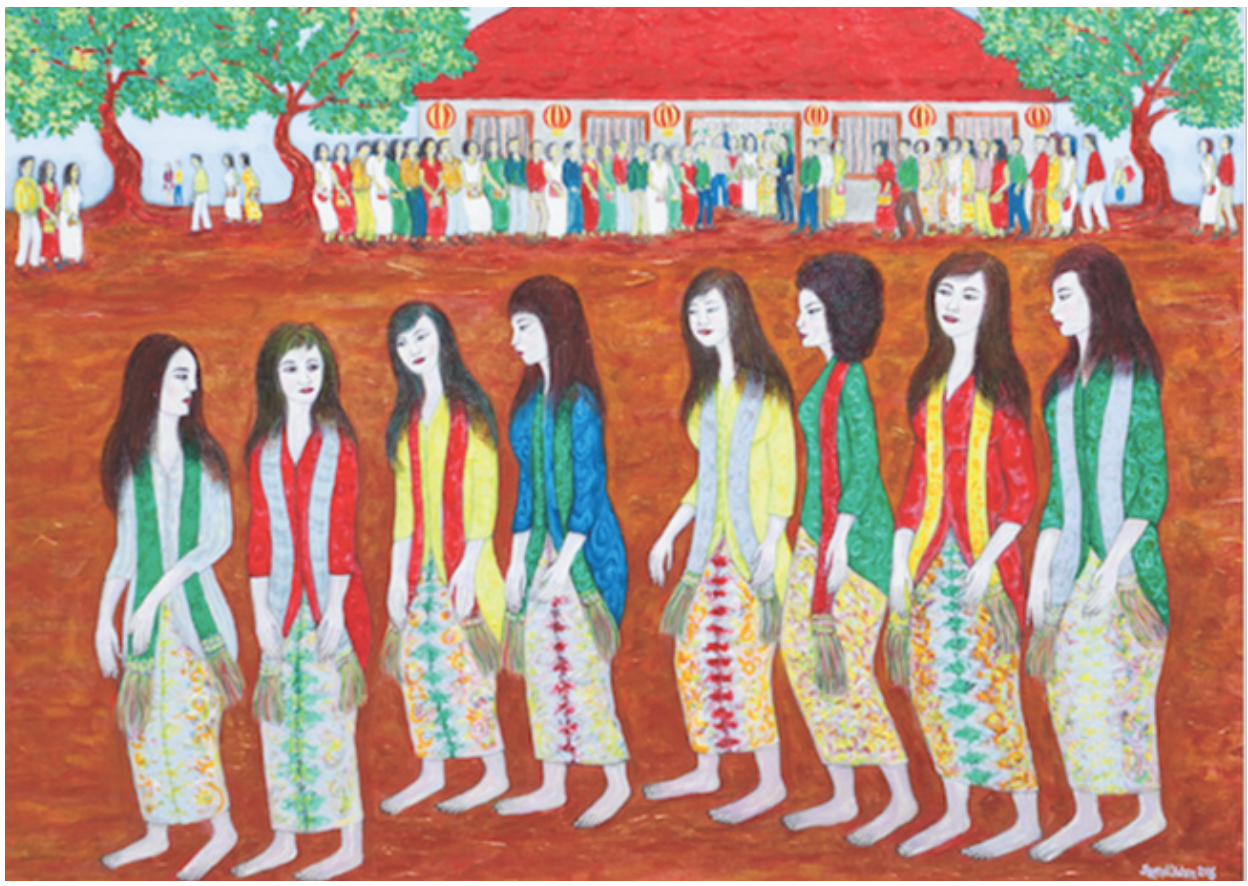

Gambar 5. Delapan Penari Cokek Sehabis Pentas di Rumah Kawin, 2016.

Ukuran\&Bahan: 140 X $120 \mathrm{~cm} /$ cat akrilik pada kanvas

mata dan goyang pinggul yang terkesan erotis dan seksi. Pewarnaan pada lukisan ini banyak menggunakan warna merah, biru, kuning dan oranye. Latar belakang lukisan menggunakan warna perak untuk menggambarkan optimisme penari Cokek dalam kehidupannya yagn sulit. Melalui lukisan ini, penulis menunjukkan empati dan keberpihakan pada penari Cokek untuk tetap bersamangat dan optimis dalam berkesenian.

Karya keenam, lukisan berjudul Cokek Pulang Kampung, menggambarkan potret dua penari Cokek yang sedang berjalan kaki di jalan setapak, dengan latar belakang sawah hijau tanpa menampakkan garis cakrawala dan langit. Busana mereka tampak tidak konsisten atau tidak sebangun. Pakaian bagian atas adalah busana Cokek, sedangkan bagian bawahnya memakai celana dengan model kekinian yang ketat dan ditambah sepatu booth berhak tinggi. Rambutnya kemerahan, yang menunjukkan rambutnya disemir. Warna lukisan ini didominasi hijau. Untuk figur dua penari cokek

sebagai pusat perhatian menggunakan warna biru pada celana, sepatu dan rambut dengan sentuhan warna merah. Warna kebaya berwarna kuning dan merah, sedangkan selendang menyesuaikan dengan warna putih, kuning dan merah. Pada bentuk jalan menggunakan warna merah dengan eksentuasi warna kuning. Lukisan ini menyimbolkan persepsi penulis tentang adanya kontradiksi budaya. Latar belakang sawah adalah simbol agraris, sedang latar depan yang diwakili oleh tampilan penari Cokek adalah hibrida antara tradisional dan modern.

Karya ketujuh, lukisan berjudul Penari Cokek Menatap Masa Depan, menggambarkan seorang penari Cokek sedang berdiri di mulut setengah pintu yang terbuka. Setengah pintu lagi masih tertutup. Penari ini seperti diapit oleh dua jendela yang berjeruji vertikal. Bagian-bagian yang menunjukkan bagian dalam rumah digambarkan seperti tanpa cahaya, dengan warna yang kehitaman dan kosong. Lukisan didominasi oleh warna oranye. Pusat perhatian bertumpu pada figur Penari Cokek yang memakai baju merah dengan latar bagian dalam rumah yang gelap.

Penari cokek dalam lukisan ini merupakan simbolisasi kegelisahan penari cokek terhadap keberadaan seni budaya Betawi terutama seni tari cokek yang kian hari kian tersingkir akibat dari keterpinggiran (tergusur) karena maraknya budaya asing atau global yang masuk ke kota Jakarta. Selain itu juga Budaya pop yang terus menggempur budaya tradisional (cokek). Karena hal tersebut cokek jarang mendapatkan undangan untuk pentas sehingga pendapatannya sangat sedikit sekali maka cokek cenderung miskin dan tidak berdaya. Posisi cokek ditempatkan berdiri di pintu, dengan pandangan menerawang ke depan. Latar belakang lukisan ini melukiskan rumah tradisional Betawi, dengan bentuk jendela di kiri dan kanan pintu utama dengan warna kuning kemerahan. Lukisan ini mempunyai makna tentang kegelisahan penari cokek terhadap masa depannya yang tidak jelas. 


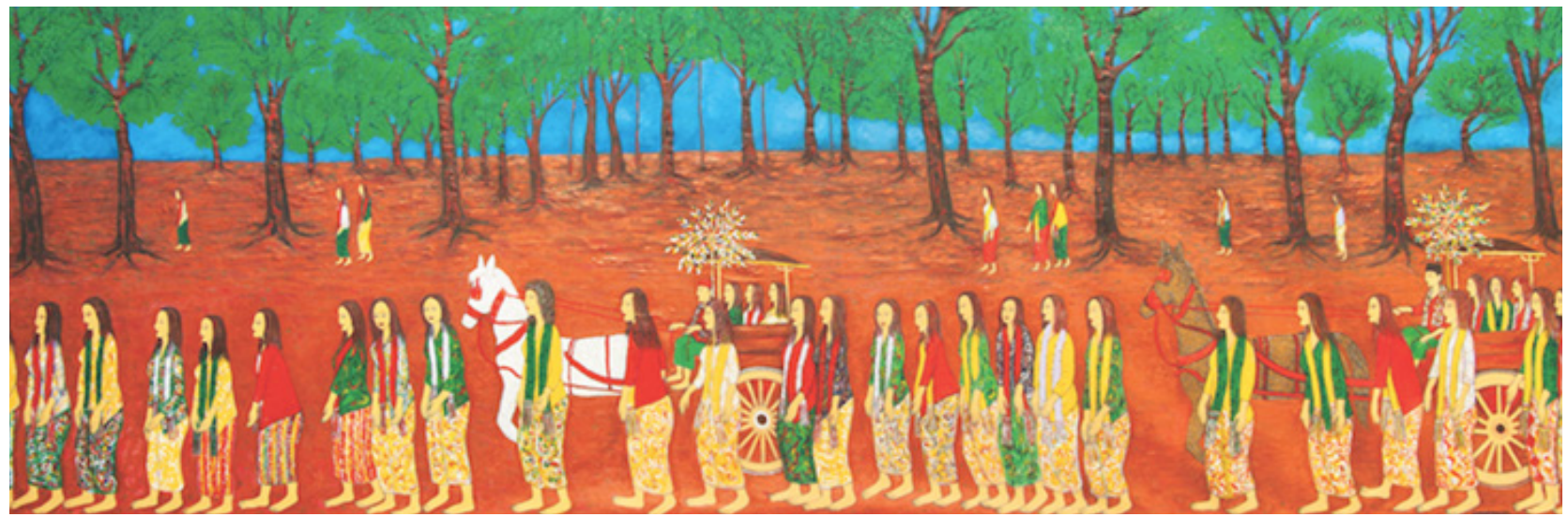

Gambar 6. Barisan Penari Cokek Menuju Rumah Kawin, 2014.

Ukuran dan Media: 160 X $300 \mathrm{~cm} /$ Cat akrilik pada kanvas

Sumber foto: dokumentasi pribadi

Secara keseluruhan, lukisan ini menyimbolkan empati penulis pada nasib Cokek yang kesepian karena ditinggalkan oleh masyarakat pendukungnya. Pintu yang terbuka setengah, menyimbolkan persepsi penulis tentang sikap Cokek yang tidak mau sepenuhnya membuka diri terhadap seni modern. Mereka cenderung kukuh untuk mempertahankan orisinalitas tari Cokek di tengah gempuran budaya modern. Sikap demikian ini menunjukkan kecintaan yang mendalam terhadap tari Cokek. Sikap ini justru dihargai oleh penulis. Kekukuhan tersebut juga ditandai dengan penggambaran jendela yang berjeruji bagaikan penjara, untuk menyatakan komitmen diri pada orisinalitas. Gambaran demikian lebih mewakili obsesi penulis daripada kenyataan yang sesungguhnya. Obsesi dari seseorang yang dirundung rindu pada Cokek sebagaimana Cokek pada masa lampau.

\section{SIMPULAN}

Penelitian ini didorong oleh kerinduan peneliti pada Tari Cokek sebagai bagian dari lingkungan budaya pada masa silam untuk menjadi inspirasi seni lukis. Penelitian dan penciptaan karya berada dalam tujuan: mengetahui dan mengungkapkan Cokek sebagai lingkungan budaya penulis pada masa silam sampai dengan keberadaannya sekarang yang tidak berdaya secara ekonomi dan terpinggirkan secara geografis; mengetahui kehidupan Cokek sebagai sumber gagasan penciptaan, dan; mengetahui dan mempraktikkan metode penciptaan seni lukis dalam tema Cokek sebagai wujud rasa rindu dan iba pada eksistensi Cokek sekarang. Manfaat esensial penelitian dan penciptaan ini adalah: sebagai ekspresi keindahan pribadi yang bermuatan rasa rindu dan iba pada Cokek sebagai bagian dari lingkungan budaya masa lalu penulis.
Setelah dilakukan studi literatur, observasi, wawancara dan pendokumentasian, ditemukan fakta, bahwa masyarakat pendukung Cokek telah semakin menurun, sehingga kesenian ini tidak berdaya untuk mempertahankan eksistensinya, ditandai dengan terpinggirnya Cokek dari pusat Jakarta ke Tangerang. Para pelaku Cokek mengalami dilema atau berada dalam pilihan yang sulit: untuk bertahan, penanggap telah semakin langka, sedangkan untuk beralih profesi mereka tidak memiliki keahlian lain karena kecintaannya pada kesenian Cokek.

Dilema tersebut, khususnya pada problem ketidakberdayaan dan keterpinggiran Cokek, menjadi sumber inspirasi utama untuk menciptakan 7 (tujuh) lukisan pasca penelitian. Adapun metode penciptaannya meliputi: eksplorasi ide, bentuk, dan teknik. Hasilnya, sebagai temuan penciptaan, adalah seni lukis dekoratif nostalgis, ialah seni lukis bercorak dekoratif yang mengaktualisasikan rasa rindu dan rasa iba pada Cokek sebagai bagian dari budaya Betawi masa silam yang kini semakin menghilang.

Hasil karya yang diciptakan merupakan simbol dari perasaan-perasaan yang merupakan uneg-uneg penulis, dengan harapan dimengerti oleh orang lain, agar orang lain juga merasakan hal yang sama kemudian peduli. Langer mendefinisikannya sebagai "kreasi bentuk-bentuk simbolis perasaan manusia", di mana sebagai bentuk simbolis seni sudah mengalami transformasi. Bentuk simbolis tidak menunjuk pada gejalanya sendiri atau pengalaman sendiri secara langsung melainkan pada pengalaman yang sudah disimbolkan, yakni menjadi ungkapan simbolis dari pengalaman tersebut. Bentuk yang dieksplorasi seniman dalam kreasi seninya itu tidak berasal dari pikirannya, melainkan dari perasaannya atau lebih tepat dikatakan sebagai formasi pengalaman emosion- 
al. Dan simbol yang berasal dari perasaan ini akan menghasilkan 'insight estetis'.

Dalam karya ini tema tentang Cokek tidak hadir secara banal dan sesuai realitas, tetapi hadir dalam penghayatan dan eksplorasi visual pencipta. Dimana pemaknaannya melalui nilai simbolik yang dapat diapresiasi bersama oleh audiens melalui kerangka imajinasi dan persepsinya masing-masing. Jadi karya-karya ini adalah jalinan makna simbolik yang dieksplorasi dari insight penulis terhadap kondisi kebudayaan sebagai bagian integral dari kehidupan penulis di Betawi yang kian terdesak oleh kehidupan modern-metropolis Jakarta.

\section{DAFTAR RUJUKAN}

Ali, Matius. 2011. Estetika Pengantar Filsafat Seni. Sanggar Luxor

Bandem, I Made. 2001. Metodologi Penciptaan Seni: Kumpulan Bahan Mata Kuliah. Yogyakarta: Program Pascasarjana ISI Yogyakarta

Campbell, David. 1986. Mengembangkan Kreativitas, saduran A.M. Mangun Hardjana. Yogyakarta: Kanisius

Langer, Suzanne K. 2006. Problematika Seni (terjemahan Fx. Widaryanto). Bandung: Sunan Ambu

Press STSI Bandung, 2006 Ratna, Nyoman Kutha. 2007. Estetika Sastra dan Budaya. Yogyakarta: Pustaka Pelajar

Sp., Soedarso. 2006. Trilogi Seni: Penciptaan, Eksistensi, dan Kegunaan Seni. Yogyakarta: Badan Penerbit Institut Seni Indonesia Yogyakarta

SP., Gustami, SP. 2007. Butir-Butir Mutiara Estetika Timur: Ide Dasar Penciptaan Seni Kriya Indonesia. Yogyakarta: Prasista, 2007 